\title{
Investment Application Model in the Sentani Lake Management to Improve the Community Economy of Customary Rights Holders
}

\begin{abstract}
The purpose of this study is to determine the conditions of investment in the management of customary rights in utilizing the potential of the Sentani Lake; and also to find a role model for equitable investment application in the Sentani Lake management to improve the community economy of customary rights holders. The research method was empirical and normative juridical to see management and utilization of the Sentani Lak, as well as the role model for equitable investment application in the Sentani Lake management. Those data obtained will be analysed systematically to obtain a comprehensive description of the problems in order to obtain results in accordance with the objectives of this study. The results of this study address that the conditions of investment in the management of customary rights in utilizing the potential of the Sentani Lake have not been running optimally because many community rights holders sell their customary rights of the edge of the lake in various rates. Indeed, this is detrimental to the community in the long term; There has been no technology transfer from investors to the community in terms of providing the role model for equitable investment application in the Sentani Lake management. The models in the management of Sentani Lake should be made in one District regulation that govern the cooperation process, the making cooperation contracts, maximum and minimum limits on rental prices, prohibitions on selling customary rights, and the process of technology transfer in the use of the Sentani Lake.
\end{abstract}

Herry. M. Polontoh *, Kadir Katjong, and Tri Yanuaria

Lecturer at Faculty of Law, Cenderawasih University Papua - Indonesia

Keywords : Investment model, the Sentani Lake management, the Community Customary Rights Holders

DOI: $10.7176 / \mathrm{JLPG} / 90-16$

Publication date:October $31^{\text {st }} 2019$

\section{Introduction}

The Sentani Lake has an area of 9,630 hectares and is located at an altitude of 75 meters above sea level. The Sentani Lake is the largest lake in Papua and its location is in Jayapura Regency. It has enormous potential in the management of the Sentani Lake because of its panoramic beauty, diversity of freshwater fish species, and the handmade of the local community handicrafts such as bark and stone paintings as the best in Papua.

Regarding to the great potential of the Sentani Lake, the local community who hold customary rights still live in poverty due to the non-optimal use of natural resources in the area. As it known, the objects of customary rights are included ${ }^{1}$ land, water such as rivers, lakes, beaches and waters, and wildly plants such as trees, fruits, and trees for carpentry or firewood, as well as animals who live on the land / customary environment either living wild or free in the forest.

Recognizing the rights of the customary law community (indigenous people) over land and natural resources in Indonesia is strongly associated with the Article $18 \mathrm{~B}$ (2) the 1945 Constitution which states that "the state recognizes and respects the unity of indigenous peoples and their traditional rights throughout alive and in accordance with the development of society and the principles of the Unitary Republic of Indonesia, as set in law". The article provides a constitutional position for the indigenous peoples in relation to the state and a constitutional basis for state administrators. It stipulates also how the indigenous peoples should be treated constitutionally by state administrators.

The lake has an important function in the lives of the indigenous peoples in the east Sentani ${ }^{2}$ because most of the people have a livelihood as fishermen. Therefore, it is necessary for state to intervene the regulation of

1 Maria S.W. Sumardjono, Puspita Serangkum Various Issues on Agrarian Law, Andi Offset, Yokyakarta, 1982, p.199.

2 The location of this study is in the East Sentani District. The width of the East Sentani area is $15,182.72$ ha. It consists of 7 (seven) villages, namely - Kampung Nolokla, Kampung Nendali, Kampung Itakiwa / Ayapo, Kampung Asei Besar, Kampung Asei Kecil, Kampung Puay, and Kampung Yokiwa. Their location are around the Sentani Lake where most of the people work as fishermen. An indication of their 
protecting those Sentani east fisherman. Article 33 paragraph (3) of the 1945 Constitution stipulates that "the earth, water and natural resources contained therein shall be controlled by the state and shall be used maximally for the prosperity of the people". This article clearly regulates the relationship between the state and the earth, water and natural resources contained therein controlled by the state, with the aim to prosper the people.

Economic growth is able to open isolation of an area and often is not integrated with the interests of people who have a way of life, values, norms and socioeconomic needs in the management of natural resources that are different from business actors. So that in the implementation level, it creates a gap between the objectives determined by the government, investor interests, and community needs. The granting of special autonomy for the Papua Province is regulated in the Law No. 21/2001 (hereinafter called the Special Autonomy Law). The Special Autonomy Law has a major impact on investment opportunities in the Papua Province. Related to investment in Papua Province, the local government must recognize, respect, protect, empower and pay attention to the rights of the indigenous peoples as a whole, of course also without ignoring the interests of investors.

The existence of legal recognition of communal land by the State is a strong basis for the indigenous peoples to control, regulate and utilize customary land. ${ }^{1}$ in Papua Province, the customary community in the management of customary land has shifted and transferred from the indigenous people to the hands of other parties. Based on the background as stated above, the focus of this paper will be the conditions of investment in the management of customary rights in utilizing the Sentani Lake and the investment application model in the Management of the Sentani Lake in order to improve the community economy of customary rights holders.

\section{The Research's Method}

The method of research was normative and empirical juridical approaches. The normative juridical approach was used to see the rules or legal norms relating to investment issues especially the management of customary rights, especially water (the Sentani lake). The empirical juridical approach was used to see or study the nature of the law that occurs in community related to investment in the management of customary rights to increase the community economy of customary rights holders.

The research conducted to obtain primary data through observation on existing problems and depth interviews to relevant respondents. ${ }^{2}$ This interview was conducted with informants consisting of 5 customary rights holders and 5 business operators of the Sentani Lake. It had interview guidelines. All data obtained through interviews were used to support those data obtained from observations.

The data were analysed descriptively. It means that the data that has been collected and grouped is then analyzed and described systematically in accordance with the reality of the facts, the characteristics and the relationship between the events being investigated so that they can be justified. This analysis provides a limit to the discussion which means there is no confusion, so that the discussion is right on target.

\section{Research Results}

3.1. Investment Conditions in the Management of Customary Rights of the Sentani Lake in Improving the Community Economy of Customary Rights Holders

The term "the Customary Rights" consists of two words, namely from the words "rights" and "ulayat customary". The word "ulayat" etymologically is identical with the meaning of region, clan, and "Nagari". The word "rights" means right, property (belonging), authority, power to do something, right power or to demand something, degree, or dignity. The word "rights" means the role of a person or party to act on something that is the object of that right. The word "authority" means the right and power to act or the power to make decisions, govern, and delegate responsibility to others. The word "region" means territory (power, government, control), regional environment. The rights literally are interpreted as the authority of customary law communities over

activity as fishermen can be seen that there are many cages of tilapia, goldfish, and koi.

$1 \quad$ Article 3 of the Law Number 5 of 1960 concerning Basic Agrarian Principles states that "by observing the Articles 1 and 2 of the implementation of customary rights and similar rights from customary law communities according to the fact there is still one, it must be such that it is in accordance with national and state certainty based on national unity, and must not be in conflict with other laws and regulations that are higher".

2 Ade Saptono, The Main Methodology of Pure Empirical Law Study: An Alternative, Tri Sakti University, Jakarta, 2009, p. 85. 
land in a particular environment / region / region to control in the sense of taking and utilizing land for the benefit of the legal community and its members. ${ }^{1}$

The Government of the Papua Province in the realm of the Special Autonomy is well aware that investment has a very important role to improve the welfare of the people. Investment activities, both domestic and even more foreign investment, will determine the speed of economic growth in a region which in turn will also affect the regional economic performance by creating new jobs. It will also enhance regional economic performance and the purchasing power of the community and also even suppress poverty rate. Through a legal system and legal regulations that can provide protection, it will create legal certainty, fairness, and efficiency for investors. ${ }^{2}$

There are various types of substances in the legislation and the substance of the contract of work made by the government with mining companies operating in Indonesia. ${ }^{3}$ The most important things to be considered by the local governments is those investors, both foreign and domestic investors, always give priority to legal and business certainty. Law is one of the most important factors in relation to legal protection provided by one country for investment activities.

The granting of the special autonomy for Papua Province is regulated in the Law Number 21 of 2001(hereinafter called the Special Autonomous Law). ${ }^{4}$ This Law has a major impact on investment opportunities in Papua Province. Regarding investment in the Papua Province, the local government must recognize, respect, protect, empower, and pay attention to the rights of indigenous peoples as a whole, of course, also without ignoring or overriding the interests of investors, mainly related to legal requirements. Some efforts to spur economic growth in development policies should be done by the local governments. It must carry out legal reforms in this case because almost all investment activities in Papua province are faced with the problem of legal uncertainty. This is due to among others of the local government regulations that impede capital inflows such as land acquisition permits and so on. It is also caused by overlapping regulations that provide reasons for investors not to dare to invest in agriculture or natural resources.

To increase the investment climate in Jayapura Regency, there is a need for legal certainty and security guarantees for investors who will invest in the management of customary rights, especially the Sentani Lake. By increasing the management of the potential utilization of the Sentani Lake, it is hoped that the economy of indigenous peoples will increase. The local government then should know and study some factors influence investors in investing their money in Papua Province and the best strategy to improve the investment climate in Jayapura Regency.

The area of the East Sentani is 15,182.72 ha. It consists of 7 (seven) villages, among others: Nolokla Village, Nontrol Village, Itakiwa / Ayapo Village, Asei Besar Village, Asei Kecil Village, Puay Village, and Yokiwa Village. The distance between the Capital District to Jayapura Regency is $\pm 36 \mathrm{~km}$ travelled by land and the distance between the Provincial Capital is $\pm 45 \mathrm{~km}$. The distance from the capital of the District to the Nearest Village is $\pm 1 \mathrm{Km}$, namely Nolokla village, and the farthest Village is Yokiwa $\pm 45 \mathrm{Km}$. the East Sentani District is the Development Area I, which is relevant to the research focus. The livelihoods of the village communities in the East Sentani District are as fishermen and ranchers where the East Sentani District area is surrounded by the Sentani Lake. There are several companies in the East Sentani District, for example, PT Buma Kumawan and PT Bintang Mas in Kampung Nendali, cage business at the edge of the Sentani Lake, Yougwa restaurant business, Kristo Restaurant located up the Sentani Lake, soil excavation business type C, and excavation business type $\mathrm{C}$ in Khalkote Lake.

In the East Sentani, there are several clans that hold customary rights to the Sentani Lake, namely Ansaka, Ohe, Kaigere, Rumoat and Doce, However, those who have remaining customary rights are the Kaigere, Ohe and

Rosnindar Sembiring, Customary Land Law, RajaGrafindo, Jakarta, 2017, p.7.

Abdul Talib, The Law of Investment and Capital Markets, Postgraduate of Legal Studies UIR,2005, p.34.

H. Salim, SH, MS, Mining Law in Indonesia, RajaGrafindo Persada, Jakarta, 2007, pp. 401-404.

4 The special autonomy of the Papua Province is granted by the Republic of Indonesia through the Law Number 21 of 2001 (Statute Book No. 135/2001 and Supplement to Statute Book No. 4151) which has been amended by Perpu No. 1 of 2008 No. 57 TLN No. 4843). The Law Number 21 of 2001 consisting of 79 Article that regulates the authority of the Papua Province in carrying out Special Autonomy. For the full material can be seen in the Special Autonomous Law. In addition to the special matters stipulated in this law, the Papua Province is still use the Law on regional governance that applies generally to all regions of Indonesia. 
Ansaka clans. ${ }^{1}$ The sign of territorial borders or area of the ownership rights of the Sentani Lake between one clan and another clan is large rocks, trees, or islands. Some clans have sold the customary rights of the Sentani Lake, for example the Ansaka clan sold customary rights in the edge of the Sentani Lake in the small Asai area to Markus Enokibor and Kristo restaurants, including Yougwa and some cages in Nendali. The price is tagged with an area of 20 square meters around Rp. 150.000.000. Indeed, the price is quite cheap comparing with the potential for economic development of customary rights holders.

The management model of the utilizing of the Sentani Lake today is most people do cultivate the Tilapia fishes in some cages and made also a floating restaurant. The use of the Sentani Lake is still done in various ways both individual and company (investor). Some investors invest their money in rental mode of the edge the Sentani Lake to Customary rights holders, for example to Simion Ohe. He have cages for rent, one box of cages ready for use, valued at Rp.40,000,000, / year, but if they lease for 2 years, the investor will get discount. He also leases the lake to the School of Law (STIH), YAPIS University, and University Otogesler, ${ }^{2}$ and to some Roasted Tilapia restaurant namely Lestari restaurants.

This is also done by the Robert Kaigere who leases his customary rights of the edge of the lake in the Asai Kecil Village. The price of it is Rp.20.000.000 / year. Mr. Doce also rents the lake edge which is his customary right with a price of Rp.10.000,000 / year. In addition to lease, Robert Kaigere also manages the Sentani Lake with the profit sharing system, where either Robert Kaigere as the owner of the lake and other parties who own capital by making cages of 60 boxes with a period of 9 years from 2001-2010. The profit sharing system is $70 \%$ for owners of capital and 30\% for owners of lakes. However, since 2011, the contract was not renewed. Robert Kaigere manages his own cages. The Sentani Lake also leased which are often referred to as water leases. It means that the business actors who want to do cage to build their own houses and dwellers for their custodian supervisors and cage plots made of wood. The rents can be seen from the area, for example, with an area of $10 \mathrm{~m}$, the value is around 3 million / month, or a box of cages with an area of $5 \times 5$, the value is around 2 million / month.

Thus, based on those data mentioned aboce, it can be concluded that there is a difference in the price of leasing rights on the edge of the Sentani Lake. Indeed, with this price difference, there is no certainty for investors in investing their money. Therefore, the management of the Sentani Lake has not been carried out optimally.

\subsection{The Model of Investment Application in the Management of the Sentani Lake to Increase the Economy} of the Community Rights Holders

Indonesia is a very large archipelagic country, with many provinces spread throughout Indonesia. The government is aware that all regions in Indonesia shall have been developed both in the economic and social fields. The big problem of the development is so far that the centralized system must be started from the Center government so that development is carried out unevenly by all groups of people. National development has several goals, one of which is to improve the standard of living of the people so that they become fully human beings based on the Pancasila and the 1945 Constitution of Indonesia. As the ideals of the Indonesian nation is to create a just and prosperous society, the implementation of development then become a very important thing.

In the context of derivation of the ideal of the Indonesian nation to the local government, something needs to be considered by local governments is that investors, both foreign and domestic investors, always give priority to legal and business certainty. Law is a very important factor in relation to the legal protection provided by a country for investment activities. Some efforts to spur economic growth in development policies should be done bt the local governments through legal reforms. This is because almost all investment activities in the Jayapura Regency are faced with the problem of legal uncertainty because some local government regulations that impede the flow of currents capital such as land permits for land acquisition and some overlapping regulations that provide reasons for the inverstors not to dare to invest in agriculture or natural resources.

To increase the investment climate in Jayapura District, the government should know and examine some factors influence the investors in investing their money in Jayapura Regency and the best strategies to improve the investment climate in the management of the Sentani Lake. Legal certainty is a protection for justice seeker against arbitrary actions, so that someone can get something that is expected in certain circumstances. The law is tasked with creating legal certainty because it aims to create order in society. In order to create legal order in

Interviewed with Robert Kaigere, August, 23, $2019: 11.30$ local time.

Interviewed with Simon Ohe, August, 5, $2019: 11.00$ local time. 
society, legal certainty must reflect justice and bring benefits to the community. According to Otto, the legal certainty ideally should fulfil five conditions. namely: ${ }^{1}$

1. The laws must be clear, consistent and accessible for all people issued by or on behalf of the State;

2. The government institutions consistently apply these laws and they themselves are subject to them;

3. In principle, these laws are in accordance with the majority of the community;

4. The existence of an independent and commercial judiciary applies these laws consistently in dispute resolution; and

5. The Judicial decisions can actually be implemented.

The five conditions as stipulated by Otto indicate that legal certainty can only be achieved if the legal substance is in accordance with the needs of the community. Thus, the rule of law is able to create legal certainty, which is actually a law should reflects the culture of society. So that it fulfils a sense of justice and of course brings benefits to the community

Legal certainty becomes an important element in creating an investment climate in an area because it is not related to investment law alone but how the law works avoiding the vagueness or uncertainty between which laws apply when dealing with the existence of legal life in a community. At it is known, in Papua, its own legal system (adat) is still very thick and this sometimes makes investors not have legal certainty especially as it relates to land rights. Regarding to the land rights, the investor must have a proof of ownership not only in the form of the certificate of land, but also the process of releasing of the land done by the customary institution called "Lembaga Adat".

Several years ago, large companies engaged in electronics such as Samsung and Panasonic shut down their company in Indonesia because most of them think that there is no legal certainty in Indonesia as stated by Samsung Electronics Indonesia General Marketing, Lee Kang Hyung. He states that the Indonesian government control in the field of law is very weak so there is no legal certainty. ${ }^{2}$ Furthermore, internal constraints occurring in the investment system in Indonesia are a separate issue for the growth of a healthy investment climate. This is due to legal issues of difficulty in obtaining suitable land or project sites, marketing and financing difficulties.

Investment is a source of regional development funds, but many cases of overlapping legal rules in the region including the reasons why many the investors who do not dare to invest in agriculture or natural resources. In addition, corruption practices still occur in many areas and is considered to be a barrier of investment activities in Indonesia. It can be said that the success of the investment system in the regions is also very dependent on the support of the local government. Some Indonesian investment cases take place because there is an inadequate demand for investors which causes high costs.

Another problem regarding the investment system is raised by the Economic Observer at Gajah Mada University, Revrisond Baswi. He states that in fact the investors had been spoiled a lot and are facilitated easily by the investment system, but the contribution of investors to the development of community welfare is still lack. The indication of it is many people poor around investment projects or business activity centres. Therefore, Revrisond addresses that all parties have to come back to see and hold on to the 1945 Constitution of Indonesia in addressing issues related to investment and also improving people's welfare.

The enactment of the Law Number 22 Year 1999 concerning Regional Government and replaced by the Law Number 32 Year 2004 becomes a legal basis for doing the investment system in local government. The substance of the Law on Regional Government is giving authority to local government to implement regional autonomy. This causes each region to have the authority to issue investment regulations. The local government should avoid some overlapping regulations between central and local authorities, and the diversity of those regulations issued by each region. This has resulted in the emergence of legal uncertainty.

To accelerate the implementation of regional development in Papua Province, the Law No. 21 of 2001 concerning Special Autonomy for the Province of Papua is enacted. This Law appears in line with the ideals and objectives of the Unitary State of the Republic of Indonesia, namely "to build a just, prosperous, of Indonesian society based on Pancasila and the 1945 Constitution, while the purpose of this Law is to regulate and manage

$1 \quad$ Kurnia, Agrarian Law in Compound Communities, HUMA, Jakarta, 2010, p. 74.

2 See Kompas, 3 May 2007, South Korea's investment assessed the weak cooperation between the central government and the local government. 
the interests of its people based on the aspirations, needs and basic rights of the people of Papua". The granting of the Special Autonomy Law has a major impact on investment opportunities in the Papua Province. Related to investment in Papua Province, the local government must recognize, respect, protect, empower and pay attention to the rights of indigenous peoples as a whole, of course also without ignoring the interests of investors. To improve the welfare of the people of Papua, the local government makes development plans and one of which is making investment development programs aimed at the short-term and long-term that are started and planned in 2003.

Implementation of a strategy on increasing investment both domestic and foreign investments in Papua Province is divided into 3 (three) time periods, namely from 2011-2015, from 2016-2020 and from 2021-2025. The formed activities in supporting the program are one-stop licensing services, increasing fund assistance roll on the community business groups, and creating number of local regulations who familiar with the programs. To realize the programs as mentioned previously then, some policy innovation and local government incentive are created through the formation of an Integrated Licensing Board and Investment of Papua Province, which is expected that with the establishment of this agency will be easier to administer permits, based on the Government Regulation No. 38/2007 concerning the division of affairs of the Central and Provincial Governments and Regency / Municipal Governments. However, in its implementation, there are still local authorities which are still handled by the central government, even though the regions are able to handle them. It happens because not all sectoral regulations are covered by the Special Autonomy Law in Papua Province.

To improve investment licensing services, the Papua government has determined the process steps and procedures for granting investment licenses with the system, One Stop Service Arrangement in order to facilitate licensing arrangements for investors to invest in Papua. Implementation of investment management licensing services in Papua Province after the implementation of the One Door Integrated Services (PTSP) in the field of investment is based on the Presidential Regulation Number 27 of 2009 concerning One Door Integrated Services in the field of investment and the Ministry Internal Affairs Regulation Number 20 of 2008 concerning Organizational Guidelines and Unit Work Procedures PTSP in the regions. In the scope of Papua Province, the implementation of PTSP is based on the Papua Governor's Regulation No. 1 of 2010 concerning the Implementation of One-Stop Integrated Services.

With the establishment of PTSP, it has helped many investors / prospective investors come to the Integrated Licensing and Investment Agency of the Province of Papua. The level of investment from 2010-2017 has increased, but the investment sector in Papua Province is currently still dominated by mining products. which is $52.46 \%{ }^{1}$ In the context of legal certainty for investors, it is more conducive for them to invest in Indonesia, including Papua. However in somehow, the overlapping of central and local policies in the investment sector still occur due to the unstable implementation of the decentralization program resulting in the confusion of authority between the central government and regional governments in investment policies. One example of overlapping policies between sectors is the prohibition of open mining activities in protected forest areas. The consequence of it has not been a deep understanding of the growth of long-term interests with short-term interests that are actually closely related to each other.

The investment climate will grow when there is synergy between the government, business actors and the community in designing an integrated, comprehensive and sustainable investment strategy in all regions of Indonesia, especially in Papua Province, which is a region of eastern Indonesia that has very high potential sources. The research results shows that regulations are still weak and the certainty of an investment effort that emphasizes the acceleration of development through the development of economic growth centres are also weak in order to open isolation of an area. Un-integrated interests between the investor and people related to the way of life, values, norms and socio-economic needs in managing natural resources. The result of it, it creates a gap between the goals set by the government, investor interests and community needs. Papuan indigenous people still uphold their custom, especially in the management of natural resources and the diversity of various primordial ties involving indigenous peoples in relation to customary rights. It is also another problem that must be faced with investors entering Papua Province.

The existence of legal recognition of customary land by the State is a strong basis for indigenous peoples to control, regulate and utilize customary land, ${ }^{2}$ but in its implementation, of course, requires legal certainty usually

Papua Province Investment Coordinating Board, Book on Capital Investment Development of PMA / PMDN Companies operating in Papua Province until the end of 2013, BKPM Papua, 2013, p.1.

2 Article 3 of the Law Number 5 of 1960 concerning Basic Agrarian Principles states that "by observing the Articles 1 
the management of customary land is left to indigenous groups. This certainly makes it difficult for investors to invest their money because the customs of one tribe to another in Papua Province are different. The customary land is also diverse and follow the rules made by the tribe that controls the customary land.

This is a separate issue for investors in Papua Province. As an illustration of the Dani, Moni, and Lani tribes. These three indigenous Papuan tribes have similarities in perspective and legal basis regarding the existence of customary land, and the absolute right to defend their customary land, but there is also the difference is in the system of release of the customary land of each tribe above. ${ }^{1}$ The_nature of the law includes aspects of legal protection for investors when carrying out investment activities. It is hoped that the legal certainty in the field of investment within the special autonomy framework of the Papua Province will improve investment in Papua.

Thus, the element of legal certainty in the management of the Sentani Lake customary rights plays an important role so it needs to be made village regulations and/or district regulations on the prohibition of the sale of customary rights in particular the Sentani Lake edge and set the same rental price in the fish cage business, as well as leasing in business restaurants around the Sentani Lake. In addition, there is a need for technology transfer from investors to the community in terms of managing the Sentani Lake potential development.

\section{Conclusions}

It can be concluded, as followings:

1. Investment Conditions in Management of Customary Rights in the Sentani Lake have not been running optimally because there are many community holders of customary rights who sell customary rights to the edge of the lake. Of course this is detrimental to the community in the long term. The different price of the rent of the edge lake makes investors and communities holding customary rights do not obtain optimal profits and until now there has been no transfer of technology from investors to the community.

2. The model of investments in the management of the Sentani Lake should be made in the District Regulation on how the process of cooperation, the cooperation contract making, maximum limit and the minimum lease rates, a ban on selling property rights, and technology transfer process in the utilization of the Sentani Lake.

\section{Bibliography}

Abdul Talib, The Law of Investment and Capital Markets, Postgraduate of Legal Studies UIR, 2005.

Ade Saptono, The Main Methodology of Pure Empirical Law Study: An Alternative, Tri Sakti University, Jakarta, 2009.

H. Salim, SH, MS, Mining Law in Indonesia, RajaGrafindo Persada, Jakarta, 2007.

Kompas, 3 May 2007, South Korea's investment assessed the weak cooperation between the central government and the local government.

Maria S.W. Sumardjono, Puspita Serangkum Various Issues on Agrarian Law, Andi Offset, Yokyakarta, 1982. Rosnindar Sembiring, Customary Land Law, RajaGrafindo, Jakarta, 2017.

and 2 of the implementation of customary rights and similar rights from customary law communities according to the fact there is still one, it must be such that it is in accordance with national and state certainty based on national unity, and must not be in conflict with other laws and regulations that are higher".

1 It assumed that if there are parties interested in utilizing the customary land for investment. All of them must go through the release of Adat in accordance with the Adat tribe which controls the customary land. These conditions require deeper study in order to produce the nature of legal certainty. 